\title{
Pengaruh Love of Money, Equity Sensitivity, dan Machiavellian Pada Persepsi Etis Mahasiswa Akuntansi
}

\author{
Ni Luh Putu Widia Ananda Sari ${ }^{1}$ \\ A.A.G.P Widanaputra ${ }^{2}$ \\ ${ }^{1,2}$ Fakultas Ekonomi dan Bisnis Universitas Udayana (Unud), Bali, Indonesia \\ e-mail: widiaananda1@gmail.com
}

\begin{abstract}
ABSTRAK
Penelitian ini bertujuan untuk menguji pengaruh love of money, equity sensitivity, dan Machiavellian sebagai aspek individu yang mempengaruhi persepsi etis. Penelitian ini dilakukan di Fakultas Ekonomi dan Bisnis Universitas Udayana. Sampel dalam penelitian ini adalah mahasiswa akuntansi angkatan 2015 program reguler siang. Banyaknya sampel yang digunakan adalah 65 responden dengan teknik non probability sampling. Hasil penelitian menemukan bahwa love of money berpengaruh negatif pada persepsi etis mahasiwa akuntansi. Hal ini berarti semakin tinggi love of money, maka semakin rendah persepsi etis mahasiswa akuntansi. Equity sensitivity berpengaruh positif pada persepsi etis mahasiswa akuntansi. Hal ini berarti semakin tinggi equity sensitivity, maka semakin tinggi persepsi etis mahasiswa akuntansi. Machiavellian berpengaruh negatif pada persepsi etis mahasiswa akuntansi. Hal ini berarti semakin tinggi Machiavellian, maka semakin rendah persepsi etis mahasiswa akuntansi.
\end{abstract}

Kata kunci: Love of money, equity sensitivity, machiavellian, persepsi etis.

\section{ABSTRACT}

This study aims to examine the effect of love of money, equity sensitivity, and Machiavellian as individual aspects that influence ethical perception. This research was conducted at Faculty of Economics and Business, Udayana University. The sample in this study is the 2015 accounting non regular program students. The number of samples used is 65 respondents with non probability sampling techniques. The results of the study found that love of money negatively affected the ethical perceptions of accounting students. This means that the higher the love of money, the lower the ethical perception of accounting students. Equity sensitivity has a positive effect on the ethical perceptions of accounting students. This means that the higher the equity sensitivity, the higher the ethical perception of accounting students. Machiavellian has a negative effect on the ethical perceptions of accounting students. This means that the higher Machiavellian, the lower the ethical perception of accounting students.

Keywords: Love of money, equity sensitivity, machiavellian, ethical perception.

\section{PENDAHULUAN}

Akuntan dalam dunia akuntansi mempunyai suatu etika yang harus dipatuhi dan dijalankan oleh setiap anggota. Kode Etik Ikatan Akuntan Indonesia ditujukan untuk digunakan sebagai panduan serta aturan bagi semua anggota, baik anggota yang berpraktek menjadi akuntan publik, terjun ke dalam 
Ni Luh Putu Widia Ananda Sari dan A.A.G.P Widanaputra. Pengaruh ...

lingkungan dunia bisnis, instansi pemerintahan, ataupun berada di lingkup pendidikan untuk memenuhi tanggung jawab profesional.

Pada kenyataannya, etika tersebut malah kerap kali dilanggar, terbukti dengan mencuatnya skandal-skandal perusahaan yang melibatkan profesi akuntan, misalnya saja skandal Olympus. Olympus adalah perusahaan dari Jepang yang pada awalnya tidak dikenal sebagai perusahaan yang bergerak di bidang fotografi, melainkan di bidang pembuatan mikroskop. Baru pada tahun 1936, Olympus terjun ke dalam bidang fotografi, ditandai dengan peluncuran kameranya yang sekaligus menjadi revolusioner pada bidang fotografi digital. Skandal manipulasi laporan keuangan Olympus merupakan salah satu skandal terbesar dalam sejarah korporasi Jepang.

Seperti yang diketahui, budaya Jepang kental akan rasa cintanya yang besar terhadap bangsanya sendiri, yang juga terjadi di dalam perusahaan. Orang-orang yang menjadi bagian dari perusahaan memiliki rasa loyal yang sangat tinggi pada perusahaan, yang malah disalahgunakan untuk menutupi segala kebobrokan yang terjadi di dalam perusahaan. Kerugian investasi yang dialami Olympus nyatanya tidak terendus pihak luar selama kurun waktu 20 tahun, sejak tahun 1980-an. Aset netto Olympus (konsolidasi) pada tahun 2006 dilaporkan sebesar 344,871 miliar yen, padahal seharusnya hanya 233,737 miliar yen. Laporan keuangan Olympus pada tahun 2007 juga telah dipalsukan, dimana aset netto dilaporkan sebesar 367,876 miliar yen, padahal sesungguhnya hanya 254,246 miliar yen. Seluruh bagian perusahaan melakukan kerja sama di dalam skandal ini, termasuk auditor 
internal yang seharusnya independen, tetapi malah ikut melakukan pelanggaran etika dengan berkolusi menutupi kerugian investasi yang dialami Olympus.

Demikian juga dengan perusahaan dalam negeri seperti skandal PT Telkom. PT Telkom adalah Badan Usaha Milik Negara yang bergerak di bidang jasa layanan teknologi informasi dan komunikasi, dan juga jaringan telekomunikasi di Indonesia. Saham PT Telkom diperdagangkan di Bursa Efek Indonesia (BEI) dengan kode "TLKM" dan New York Stock Exchange (NYSE) dengan kode "TLK". Untuk pertama kalinya di Indonesia terjadi perselisihan auditor, yaitu antara KAP Eddy Pianto (EP) sebagai auditor PT Telkom, dengan KAP Hadi Sutanto (HS) sebagai auditor anak perusahaan PT Telkom, yaitu PT Telkomsel. Inti persoalan dari skandal ini adalah Eddy Pianto Simon dari KAP EP merasa dirugikan oleh KAP HS, karena dinilai telah menghambat karir dan kinerjanya, dikarenakan KAP HS tidak mengizinkan KAP EP untuk menggunakan hasil audit KAP HS terhadap laporan keuangan PT Telkomsel ke dalam laporan audit (konsolidasi) PT Telkom.

KAP EP merupakan partner dari Grant Thornton Internasional yang termasuk auditor tujuh besar dunia, sedangkan KAP HS merupakan partner dari PricewaterHouseCooper (PwC) yang termasuk auditor lima besar dunia. KAP HS meragukan kompetensi KAP EP sebagai auditor yang termasuk tujuh besar dunia, sehingga menolak untuk mengizinkan KAP EP menggunakan hasil audit KAP HS terhadap PT Telkomsel untuk menghindari jikalau ada masalah di kemudian hari. Dan benar saja, laporan keuangan PT Telkom yang diaudit KAP EP ditolak oleh SEC (Securities and Exchange Commission), Bapepam Amerika Serikat. 
Ni Luh Putu Widia Ananda Sari dan A.A.G.P Widanaputra. Pengaruh ...

Pada akhirnya, KAP HS terbukti bersalah dan mengakibatkan rusaknya kualitas audit KAP EP atas Laporan Keuangan Konsolidasi PT. Telkom tahun buku 2002. KAP HS tersebut terbukti menghalangi KAP EP untuk bersaing dengannya dalam penyediaan layanan audit ke perusahaan besar. Seharusnya, sesama anggota KAP, wajib untuk saling memelihara citra profesi dan tidak melakukan perkataan dan perbuatan yang dapat merusak reputasi rekan seprofesi.

Mencuatnya skandal-skandal ini berdampak negatif kepada kepercayaan masyarakat terhadap profesi akuntan dan dengan etika profesional akuntan itu sendiri. Etika profesional seorang akuntan sangatlah penting dalam penentuan status dan kredibilitas profesi di bidang akuntansi (Chan dan Leung, 2006 dalam Charismawati, 2011). Terungkapnya skandal-skandal tersebut menandakan diperlukannya upaya-upaya untuk mengembalikan kepercayaan masyarakat terhadap profesi akuntansi. Profesi akuntansi menekankan pentingnya para profesional mengembangkan perilaku etis mulai dari awal karirnya, bahkan sebelum menggeluti profesi tersebut (Elias, 2008 dalam Charismawati, 2011) oleh sebab itu pendidikan mengenai etika mulai harus ditanamkan dengan benar kepada mahasiswa akuntansi pada saat masih duduk di bangku kuliah, sebelum memasuki dunia kerja. Menurut Fatoki (2015), mahasiswa memiliki kecintaan tinggi terhadap uang yang diukur dengan empat faktor yaitu motivator, kesuksesan, kepentingan, dan kekayaan. Individu yang tidak menerima pembelajaran etika, 2,05 kali cenderung untuk menunjukkan perilaku Machiavellian daripada individu yang menerima pembelajaran etika (Pekdemir \& Turan, 2015). 
Tujuan dari pendidikan akuntansi menurut Bedford Committee salah satunya adalah untuk mengenalkan mahasiswa kepada nilai-nilai dan standar-standar etis dalam profesi akuntan. Kepedulian terhadap etika harus diawali dari kurikulum akuntansi, jauh sebelum mahasiswa akuntansi masuk di dunia profesi akuntansi (Mastracchio, 2005 dalam Charismawati, 2011). Mahasiswa akuntansi sekarang adalah para profesional di masa depan dan dengan pendidikan etika yang baik dapat menguntungkan profesinya dalam jangka panjang (Madison, 2002 dalam Charismawati, 2011). Terdapat beberapa faktor yang mendorong seseorang untuk melanggar persepsi etisnya, salah satunya adalah uang. Uang dipandang sebagai suatu faktor yang penting dalam kehidupan sehari-hari. Di Amerika, banyaknya uang dan besarnya pendapatan yang dihasilkan menjadi acuan untuk mengukur kesuksesan seseorang (Ellias, 2009 dalam Aziz dan Taman, 2015). Para profesor Amerika dengan pendapatan tinggi, memiliki kecintaan yang kuat pada uang (Luna-Arocas \& Tang, 2015).

Penelitian yang dilakukan oleh Tang dan Chen (2008) menguji sebuah variabel psikologis baru, yaitu individu yang cinta akan uang (love of money) yang menghasilkan sebuah pengukuran yang disebut dengan Money Ethic Scale (MES) yang digunakan untuk mengukur perasaan subjektif seseorang terhadap uang. Dalam konteks materialisme, uang dianggap melambangkan kekuatan dan prestasi (Lemrová, et al., 2014). Penelitian Tang dan Chiu (2003) menunjukkan bahwa karyawan Hong Kong dengan love of money lebih tinggi memiliki kepuasan kerja yang lebih kecil daripada teman kerjanya, sehingga terdapat kemungkinan melakukan tindakan-tindakan yang tidak etis. Penelitian tersebut 
Ni Luh Putu Widia Ananda Sari dan A.A.G.P Widanaputra. Pengaruh ...

juga menunjukkan hubungan yang signifikan antara love of money dan perilaku tidak etis dan memberi label love of money merupakan akar dari kejahatan. Penelitian Kase, dkk (2017) menunjukkan bahwa love of money berpengaruh positif pada tax evasion tendency. Hasil tersebut menunjukkan bahwa semakin tinggi love of money individu maka cenderung melakukan tax evasion dan sebaliknya semakin rendah love of money individu maka cenderung tidak melakukan tax evasion. Kecintaan individu yang tinggi terhadap uang menimbulkan niat tidak etis untuk melakukan suatu kecurangan (Chen, et al., 2014).

Penelitian lain yang terkait dengan love of money dan pengaruhnya terhadap persepsi etis mahasiswa akuntansi adalah penelitian oleh Aziz dan Taman (2015) yaitu love of money berpengaruh negatif terhadap persepsi etis mahasiswa akuntansi Universitas Negeri Yogyakarta. Penelitian ini sejalan dengan penelitian Sugiantari dan Widanaputra (2016) yang menunjukkan bahwa love of money berpengaruh negatif pada persepsi mahasiswa akuntansi tentang krisis etika akuntan, akan tetapi penelitian yang dilakukan oleh Rindayanti (2017) menyatakan bahwa love of money tidak berpengaruh terhadap perilaku etis mahasiswa akuntansi.

Persepsi etis mahasiswa juga dapat dipengaruhi oleh equity sensitivity. Miles, et al., (1994) mendefinisikan equity sensitivity sebagai variabel personalitas yang menunjukkan reaksi individu pada perasaan adil atau tidak adil. Menurut Huseman, et al., 1994 dalam Allen, et al., 2015, setiap individu dapat dikategorikan menjadi 3 kategori yaitu sebagai benevolent (givers), equity 
sensitivity, dan entitleds (getters). Equity sensitivity berada di antara benevolent dan entitleds, yang menggambarkan persepsi individu terhadap keseimbangan antara input dengan outcome.

Hasil penelitian yang dilakukan oleh Susanti (2014) mengemukakan bahwa equity sensitivity tidak berpengaruh terhadap perilaku etis akuntan, akan tetapi penelitian yang dilakukan oleh Widiastuti dan Nugroho (2015) menemukan bukti bahwa terdapat pengaruh equity sensitivity terhadap perilaku etis auditor. Penelitian ini sejalan dengan penelitian yang dilakukan oleh Kusuma dan Budisantosa (2016) yang mengemukakan bahwa equity sensitivity berpengaruh positif terhadap perilaku etis auditor.

Faktor lain yang mendorong seseorang melanggar persepsi etisnya adalah Machiavellianisme. Machiavellianisme didefinisikan oleh Christie dan Geis (1970) dalam K. Miller, et al., (2015) sebagai sebuah proses dimana manipulator mendapatkan lebih banyak reward dibandingkan yang dia peroleh ketika tidak melakukan manipulasi, ketika orang lain mendapatkan lebih kecil, minimal dalam jangka pendek. Richmond (2001) dalam Aziz dan Taman (2015) menemukan bukti bahwa kepribadian individu mempengaruhi perilaku etis. Richmond menginvestigasi hubungan paham Machiavellianisme yang membentuk suatu tipe kepribadian yang disebut sifat Machiavellian serta pertimbangan etis dengan kecenderungan perilaku individu dalam mengahadapi dilema-dilema etika (perilaku etis). Machiavellian dipandang sebagai individu yang manipulatif (Belschak, et al., 2015). 
Ni Luh Putu Widia Ananda Sari dan A.A.G.P Widanaputra. Pengaruh ...

Hasil penelitian yang dilakukan oleh Aziz dan Taman (2015) menyatakan bahwa Machiavellian berpengaruh negatif terhadap persepsi etis mahasiswa akuntansi Universitas Negeri Yogyakarta. Novitasari (2016) juga menyatakan bahwa perilaku Machiavellian berpengaruh negatif terhadap persepsi etis mahasiswa akuntansi Universitas Negeri Yogyakarta. Penelitian ini sejalan dengan penelitian yang dilakukan oleh Rindayanti (2017) yang menyatakan bahwa Machiavellian berpengaruh terhadap perilaku etis mahasiswa akuntansi.

Individu dengan love of money yang tinggi memiliki rasa cinta yang begitu besar terhadap uang dan sangat mendewakan uang. Ketika individu ini ingin memenuhi hasrat terhadap uang, di saat itu pula timbul dilema-dilema etika dalam diri individu, dimana individu yang persepsi etisnya rendah, tidak mampu memproses persepsi etis yang lebih tinggi, sehingga tidak dapat melakukan kontrol terhadap keinginan individu akan uang. Hal ini sesuai dengan teori perkembangan moral kognitif yang menekankan kepada proses berpikir moral, apa yang dipikirkan seorang individu dalam menghadapi sebuah dilema etika (Mintchik \& Farmer, 2009 dalam Yeltshinta, 2013). Menurut Richmond (2001) dalam Sugiantari dan Widanaputra (2016) teori perkembangan moral kognitif mengasumsikan individu dengan pertimbangan etis rendah tidak mampu memproses pertimbangan etis yang lebih tinggi. Keinginan yang besar pada diri individu terhadap uang menjadikan individu tersebut kemudian buta dan lalai sehingga melakukan segala cara, termasuk jalan pintas sekalipun yang melanggar persepsi etisnya. 
Penelitian mengenai love of money dan pengaruhnya terhadap persepsi etis mahasiswa akuntansi adalah penelitian Charismawati (2011) yang menyimpulkan bahwa terdapat hubungan antara tingkat love of money pada mahasiswa akuntansi dengan persepsi etis. Semakin besar tingkat love of money mahasiswa akuntansi, maka akan semakin rendah tingkat persepsi etis. Penelitian ini sejalan dengan penelitian Aziz dan Taman (2015) yaitu love of money berpengaruh negatif terhadap persepsi etis mahasiswa akuntansi Universitas Negeri Yogyakarta dan didukung oleh penelitian yang dilakukan oleh Sugiantari dan Widanaputra (2016) yang menunjukkan bahwa love of money berpengaruh negatif pada persepsi mahasiswa akuntansi tentang krisis etika akuntan.

$\mathrm{H}_{1}$ : Semakin tinggi love of money maka semakin rendah persepsi etis.

Equity sensitivity dapat dipahami sebagai keadilan yang dirasakan oleh individu dengan membandingkannya dengan individu lain. Individu dapat dikategorikan menjadi 3 yaitu benevolent, equity sensitivity, dan entitleds. Individu dengan benevolent adalah individu yang lebih suka memberi, dalam artian individu ini tidak mempersalahkan jika input lebih besar daripada outcome jika dibandingkan dengan comparison person. Individu dengan entitleds adalah individu yang lebih suka menerima, dalam artian individu ini akan merasa kurang puas jika outcome yang didapatkannya lebih kecil dari input jika dibandingkan dengan comparison person. Equity sensitivity adalah individu yang merasa puas jika input dan outcome individu tersebut sama dengan input dan outcome comparison person. Hal ini sejalan dengan teori keseimbangan yang menyatakan 
Ni Luh Putu Widia Ananda Sari dan A.A.G.P Widanaputra. Pengaruh ...

bahwa jika tingkat rasio perbandingan individu menunjukkan keseimbangan dengan rasio individu lainnya, maka individu tersebut akan merasa puas.

Penelitian yang dilakukan oleh Utami (2005) menyebutkan bahwa mahasiswa jurusan akuntansi yang termasuk dalam kategori benevolent secara signifikan terbukti memiliki perilaku yang lebih etis daripada mahasiswa jurusan akuntansi yang termasuk dalam kategori entitleds. Hasil penelitian yang dilakukan oleh Widiastuti dan Nugroho (2015) menemukan bukti bahwa terdapat pengaruh equity sensitivity terhadap perilaku etis auditor. Kusuma dan Budisantosa (2016) juga mengemukakan bahwa equity sensitivity berpengaruh positif terhadap perilaku etis auditor.

$\mathrm{H}_{2}$ : Semakin tinggi equity sensitivity maka semakin tinggi persepsi etis.

Selain dipengaruhi oleh love of money dan equity sensitivity, persepsi etis mahasiswa akuntansi juga dipengaruhi oleh perilaku Machiavellian. Perilaku Machiavellian dianggap sebagai faktor tambahan yang mempengaruhi seseorang untuk berprilaku tidak etis. Mc Laughlin (1970) dalam Novitasari (2016) menyebutkan bahwa seseorang dengan perilaku Machiavellian cenderung untuk berbohong. Machiavellian didefinisikan sebagai suatu proses dimana manipulator mendapatkan imbalan lebih ketika melakukan memanipulasi, sementara orang lain mendapatkan kurang tanpa melakukan manipulasi, setidaknya dalam konteks langsung (Richmond, 2001 dalam Yeltshinta, 2013). Individu dengan Machiavellian adalah seorang manipulator dengan moral rendah yang melakukan memanipulasi demi untuk mendapatkan imbalan/ reward. Hal ini sejalan dengam teori perkembangan moral kognitif yang menyatakan bahwa ada kategorisasi dan 
klasifikasi perkembangan moral ke dalam tiga tahap yang berbeda. Tahapan yang paling rendah (pre-conventional), individu akan melakukan suatu tindakan karena berdasarkan imbalan.

Penelitian yang dilakukan oleh Aziz dan Taman (2015) menyatakan bahwa Machiavellian berpengaruh negatif terhadap persepsi etis mahasiswa akuntansi Universitas Negeri Yogyakarta. Hasil penelitian yang dilakukan oleh Novitasari (2016) juga menyatakan bahwa perilaku Machiavellian berpengaruh negatif terhadap persepsi etis mahasiswa akuntansi Universitas Negeri Yogyakarta. Penelitian Prabowo (2016) menyatakan bahwa secara parsial Machiavellianisme berpengaruh negatif terhadap persepsi etis mahasiswa akuntansi tingkat akhir di Universitas Dian Nuswantoro Semarang.

$\mathrm{H}_{3}$ : Semakin tinggi Machiavellian maka semakin rendah persepsi etis.

\section{METODE PENELITIAN}

Penelitian ini dilakukan pada mahasiswa angkatan 2015 program studi akuntansi, Fakultas Ekonomi dan Bisnis Universitas Udayana program reguler siang, yang beralamat di Jalan P.B. Sudirman, Denpasar. Obyek penelitian ini adalah persepsi etis mahasiswa akuntansi yang dijelaskan dengan love of money, equity sensitivity, dan Machiavellian.

Populasi pada penelitian ini adalah mahasiswa program studi akuntansi angkatan 2015 Fakultas Ekonomi dan Bisnis Universitas Udayana program reguler siang. Alasan pemilihan populasi ini karena mahasiswa program studi akuntansi angkatan 2015 Fakultas Ekonomi dan Bisnis Universitas Udayana 
program reguler siang telah mengambil hampir semua mata kuliah dan sedang menempuh semester 7 , jadi dianggap telah memahami dan mendapatkan ilmu yang cukup mengenai persepsi etis, serta angkatan 2015 adalah angkatan yang selanjutnya akan menempuh dunia kerja.

Adapun teknik non probability sampling yang digunakan adalah teknik sampling aksidental. Teknik ini dipilih karena mahasiswa program studi akuntansi Universitas Udayana angkatan 2015 program reguler siang sebagian besar telah menyelesaikan studinya, sehingga sulit untuk di temui di lokasi penelitian, yaitu Fakultas Ekonomi dan Bisnis Universitas Udayana, maka dari itu teknik sampling aksidental ini paling cocok untuk digunakan dalam penelitian ini.

Agar jumlah sampel yang diambil dari populasi yang digunakan betul-betul representatif, maka untuk menetapkan jumlah sampel dihitung dengan menggunakan rumus Slovin yang menggunakan nilai kritis sebesar 0,10.

Rumus: $\frac{\mathrm{N}}{1+\mathrm{N}\left(\mathrm{e}^{\mathrm{2}}\right)}=\frac{184}{1+184\left(0.10^{2}\right)}=64,78$

Keterangan:

$\mathrm{N}=$ Jumlah populasi

$\mathrm{e}=$ Batas ketelitian yang digunakan

Berdasarkan perhitungan di atas maka jumlah sampel dalam penelitian ini adalah sebanyak 64,78 yang kemudian dibulatkan menjadi 65. Dengan demikian jumlah sampel dalam penelitian ini adalah 65 responden.

Untuk mengetahui hubungan antar lebih dari dua variabel, yaitu satu variabel sebagai variabel dependen dan beberapa variabel lain sebagai variabel independen, maka dilakukan analisis regresi linier berganda. Formulasi pengujian hipotesis dengan analisis regresi linier berganda sebagai berikut: 
$\mathrm{Y}=\alpha+\beta_{1} \mathrm{X}_{1}+\beta_{2} \mathrm{X}_{2}+\beta_{3} \mathrm{X}_{3}+\varepsilon$

Keterangan:

$\begin{array}{ll}\alpha & : \text { Konstanta } \\ \beta_{1}-\beta_{3} & : \text { Koefisien regresi variabel independen } \\ \mathrm{X}_{1} & : \text { Love of Money } \\ \mathrm{X}_{2} & : \text { Equity Sensitivity } \\ \mathrm{X}_{3} & : \text { Machiavellian } \\ \mathrm{Y} & : \text { Persepsi Etis Mahasiswa Akuntansi } \\ \varepsilon & : \text { Standar } \text { error }\end{array}$

\section{HASIL DAN PEMBAHASAN}

Model regresi yang baik memiliki distribusi data normal atau yang mendekati normal. Data penelitian dikatakan berdistribusi normal apabila nilai Asymp. Sig. (2-tailed) lebih besar daripada level of significant yang dipakai yaitu 0,05.

Tabel 1.

Hasil Uji Normalitas

\begin{tabular}{llr}
\hline & & $\begin{array}{c}\text { Unstandardized } \\
\text { Residual }\end{array}$ \\
\hline $\mathrm{N}$ & & 65 \\
Normal Parameters & Mean &, 0000000 \\
& Std. Deviation & 3,12301433 \\
Most Extreme Differences & Absolute &, 097 \\
& Positive &, 097 \\
Kolmogorov-Smirnov Z & Negative &,- 060 \\
Asymp. Sig. (2-tailed) & &, 784 \\
Sumber: Data diolah, 2019 & &, 570 \\
\hline
\end{tabular}

Berdasarkan Tabel 1 dapat dilihat bahwa nilai Kolmogrov-Smirnov sebesar 0,784 dan nilai Asymp. Sig. (2-tailed) sebesar 0,570 yang di mana lebih besar dari level of significant yang dipakai yaitu 0,05, sehingga dapat dinyatakan bahwa data berdistribusi secara normal.

Uji multikolinearitas bertujuan untuk mengetahui hubungan yang bermakna atau berkorelasi antara variabel bebas dalam suatu model regresi. Model regresi dikatakan baik jika tidak terjadi korelasi di antara variabel bebas. Jika terdapat 
Ni Luh Putu Widia Ananda Sari dan A.A.G.P Widanaputra. Pengaruh ...

gejala multikolinear di dalam suatu regresi dan dipaksakan untuk digunakan, maka akan memberian hasil prediksi yang menyimpang. Multikolinearitas dapat dilihat dari nilai tolerance atau variance inflation factor (VIF). Jika tolerance lebih besar atau sama dengan $10 \%$ atau VIF lebih kecil atau sama dengan 10 , maka model telah bebas dari masalah multikolinearitas.

Tabel 2.

Hasil Uji Multikolinearitas

\begin{tabular}{llcc}
\hline \multirow{2}{*}{ Model } & & \multicolumn{2}{c}{ Collinearity Statistics } \\
\cline { 3 - 4 } & (Constant) & Tolerance & VIF \\
\cline { 2 - 3 } & Love of Money &, 337 & 2,965 \\
& & & \\
& Equity Sensitivity &, 362 & 2,765 \\
& Machiavellian &, 745 & 1,342 \\
\hline
\end{tabular}

Sumber: Data diolah, 2019

Tabel 2 menunjukkan bahwa masing-masing nilai tolerance dan VIF dari semua variabel bebas yaitu love of money, equity sensitivity, dan Machiavellian lebih besar dari $10 \%$ dan nilai VIF yang lebih kecil dari 10, sehingga dapat diartikan bahwa di dalam penelitian ini tidak terdapat gejala multikolinearitas antara variabel bebas.

Tujuan uji heteroskedastisitas adalah untuk menguji apakah dalam model regresi terjadi ketidaksamaan varian dari residu satu pengamatan ke pengamatan yang lain. Jika varian dari residu satu pengamatan ke pengamatan lain tetap maka disebut homokedastisitas dan sebaliknya jika berbeda maka disebut heteroskedastisitas. Model regresi yang baik adalah homokedastisitas atau tidak terjadi heteroskedastisitas. Masalah heteroskedasitas akan menimbulkan variabel predictor yang akan menjadi tidak efisien. Masalah tersebut dapat dideteksi dengan uji Glejser Test yaitu dengan meregresi nilai absolut residual model yang 
destimasi terhadap variabel-variabel independen dengan memperhatikan nilai tstatistik dan signifikansinya. Jika nilai signifikansinya lebih kecil dari 0,05 maka terjadi heteroskedastisitas dan sebaliknya apabila nilai signifikansinya lebih besar atau sama dengan 0,05 maka tidak terjadi heteroskedastisitas.

Tabel 3.

Hasil Uji Heteroskedastisitas

\begin{tabular}{|c|c|c|c|c|c|c|}
\hline & \multirow[b]{2}{*}{ Model } & \multicolumn{2}{|c|}{$\begin{array}{l}\text { Unstandardized } \\
\text { Coefficients }\end{array}$} & \multirow{2}{*}{$\begin{array}{c}\begin{array}{c}\text { Standardized } \\
\text { Coefficients }\end{array} \\
\text { Beta }\end{array}$} & \multirow[b]{2}{*}{$\mathrm{T}$} & \multirow[b]{2}{*}{ Sig. } \\
\hline & & $\mathrm{B}$ & Std. Error & & & \\
\hline \multirow[t]{5}{*}{1} & (Constant) & $-2,825$ & 3,157 & &,- 895 & ,374 \\
\hline & Love of Money & ,021 & ,013 & ,352 & 1,694 & ,095 \\
\hline & Equity & & & & &, 502 \\
\hline & Sensitivity & 039 & 059 & 136 &, 675 & \\
\hline & Machiavellian & ,029 & ,032 &, 125 &, 893 &, 376 \\
\hline
\end{tabular}

Berdasarkan Tabel 3 dapat diamati bahwa nilai Sig. (signifikansi) dari masing-masing variabel yaitu love of money, equity sensitivity, dan Machiavellian adalah $0,095,0,502$, dan 0,376 yang lebih besar dari 0,05 yang berarti seluruh variabel terbebas dari masalah heteroskedastisitas.

Hasil uji analisis regresi linier berganda dapat dilihat pada tabel 4.

Tabel 4.

Hasil Uji Analisis Regresi Linier Berganda

\begin{tabular}{|c|c|c|c|c|c|c|}
\hline \multirow[b]{2}{*}{ Model } & & \multicolumn{2}{|c|}{ Unstandardized Coefficients } & \multirow{2}{*}{$\begin{array}{c}\begin{array}{c}\text { Standardized } \\
\text { Coefficients }\end{array} \\
\text { Beta } \\
\end{array}$} & \multirow[b]{2}{*}{$\mathrm{T}$} & \multirow[b]{2}{*}{ Sig. } \\
\hline & & $\mathrm{B}$ & Std. Error & & & \\
\hline \multirow[t]{5}{*}{1} & (Constant) & 45,883 & 5,405 & & 8,490 &, 000 \\
\hline & Love of Money &,- 119 &, 022 &,- 525 & $-5,505$ &, 000 \\
\hline & Equity & & & & & \\
\hline & Sensitivity & ,289 &, 100 & ,265 & 2,882 &, 005 \\
\hline & Machiavellian &,- 210 &, 055 &,- 245 & $-3,816$ &, 000 \\
\hline
\end{tabular}

Berdasarkan Tabel 4 maka dapat disusun persamaan regresi sebagai berikut:

$$
Y=45,833-0,119 X_{1}+0,289 X_{2}-0,210 X_{3}+e
$$

Keterangan:
$\alpha$
$\beta_{1}-\beta_{3}$
: Konstanta
: Koefisien regresi variabel independen 


$\begin{array}{ll}\mathrm{X}_{1} & \text { : Love of Money } \\ \mathrm{X}_{2} & : \text { Equity Sensitivity } \\ \mathrm{X}_{3} & : \text { Machiavellian } \\ \mathrm{Y} & : \text { Persepsi Etis Mahasiswa Akuntansi } \\ \varepsilon & : \text { Standar error }\end{array}$

Nilai konstanta $(\alpha)$ sebesar 45,833 memiliki arti bahwa jika variabel love of money $\left(\mathrm{X}_{1}\right)$, equity sensitivity $\left(\mathrm{X}_{2}\right)$, dan Machiavellian $\left(\mathrm{X}_{3}\right)$ dinyatakan konstan pada angka 0 (nol), maka nilai terhadap Persepsi Etis Mahasiswa Akuntansi (Y) akan meningkat sebesar 45,833.

Nilai koefisien $\left(\beta_{1}\right)$ sebesar $-0,119$ memiliki arti bahwa apabila variabel love of money $\left(\mathrm{X}_{1}\right)$ meningkat, maka akan mengakibatkan penurunan pada persepsi etis mahasiswa akuntansi $(\mathrm{Y})$, dengan asumsi variabel bebas lainnya konstan.

Nilai koefisien $\left(\beta_{2}\right)$ sebesar 0,289 memiliki arti bahwa apabila variabel equity sensitivity $\left(\mathrm{X}_{2}\right)$ meningkat, maka akan mengakibatkan peningkatan pada persepsi etis mahasiswa akuntansi (Y), dengan asumsi variabel bebas lainnya konstan.

Nilai koefisien $\left(\beta_{3}\right)$ sebesar $-0,210$ memiliki arti bahwa apabila variabel Machiavellian $\left(\mathrm{X}_{3}\right)$ meningkat, maka akan mengakibatkan penurunan pada persepsi etis mahasiswa akuntansi (Y), dengan asumsi variabel bebas lainnya konstan.

Nilai koefisien determinasi menunjukkan seberapa jauh kemampuan variabel independen dalam menerangkan variasi variabel dependen. Nilai $R^{2}$ yang digunakan adalah adjusted $\mathrm{R}^{2}$ karena ini merupakan salah satu indikator untuk mengetahui pengaruh penambahan satu variabel independen ke dalam satu persamaan regresi. 
Tabel 5.

Hasil Uji Koefisien Determinasi

\begin{tabular}{lrrrrr}
\hline Model & R & \multicolumn{2}{c}{ R Square } & Adjusted R Square & \multicolumn{2}{c}{$\begin{array}{c}\text { Std. Error of the } \\
\text { Estimate }\end{array}$} \\
\hline 1 &, $902^{\text {a }}$ &, 813 &, 804 & 3,199 \\
\hline
\end{tabular}

Sumber: Data diolah, 2019

Berdasarkan Tabel 5 dapat dilihat bahwa nilai Adjusted $R$ Square adalah sebesar 0,804 atau $80 \%$ yang berarti bahwa $80 \%$ variasi persepsi etis mahasiswa akuntansi dipengaruhi oleh love of money, equity sensitivity, dan Machiavellian, sedangkan sisanya sebesar $20 \%$ dipengaruhi oleh faktor lain di luar model penelitian.

Uji kelayakan model atau uji $\mathrm{F}$ digunakan untuk menguji kelayakan atau validitas dari suatu model regresi berganda serta untuk mengetahui apakah model penelitian dapat digunakan untuk memprediksi variabel dependen. Hasil uji $\mathrm{F}$ dapat dilihat pada tabel ANOVA dan nilai probabilitas F hitung ditunjukkan pada kolom Sig. Jika signifikansi anova $<\alpha($ alpha) 0,05 maka model dikatakan layak dan sebaliknya jika signifikansi anova $>\alpha($ alpha) 0,05 maka model dikatakan tidak layak.

Tabel 6.

Hasil Uji Kelayakan Model (Uji F)

\begin{tabular}{llccccc}
\hline Model & & Sum of Squares & Df & Mean Square & F & Sig. \\
\hline 1 & Regression & 2715,394 & 3 & 905,131 & 88,453 &, $000^{\mathrm{a}}$ \\
& Residual & 624,206 & 61 & 10,233 & & \\
& Total & 3339,600 & 64 & & & \\
\hline
\end{tabular}

Sumber: Data diolah, 2019

Berdasarkan Tabel 6, dapat dilihat bahwa Sig. memiliki nilai sebesar 0,000 yang lebih kecil daripada 0,05 . Ini berarti bahwa model regresi dalam penelitian ini adalah layak dan dapat digunakan untuk memprediksi variabel dependen.

Berdasarkan hasil pengujian analisis regresi linier berganda pada Tabel 4 dapat diketahui bahwa nilai koefisien $\left(\beta_{1}\right)$ sebesar $-0,119$ dengan tingkat 
Ni Luh Putu Widia Ananda Sari dan A.A.G.P Widanaputra. Pengaruh ...

signifikansi sebesar 0,000. Sig. t pengaruh love of money pada persepsi etis mahasiswa akuntansi adalah 0,000 yang lebih kecil dari 0,05 yang berarti bahwa $\mathrm{H}_{0}$ ditolak dan $\mathrm{H}_{1}$ diterima. Hal ini menunjukkan bahwa love of money berpengaruh terhadap persepsi etis mahasiswa akuntansi. Hipotesis pertama yang menyatakan semakin tinggi love of money maka semakin rendah persepsi etis terbukti.

Berdasarkan hasil analisis dalam penelitian ini, didapatkan nilai minimum love of money sebesar 49, nilai maksimum sebesar 161 dan nilai mean sebesar 113,23, sehingga skala love of money yang diukur dengan menggunakan Money Ethic Scale (MES), dapat dijabarkan seperti di dalam Tabel 7 berikut.

Tabel 7.

Klasifikasi Variabel Love of Money

\begin{tabular}{ccc}
\hline Rentang Klasifikasi & Klasifikasi & Rata-rata Data Responden \\
\hline $49,00 \leq$ Love of Money $<71,40$ & Sangat Rendah & \\
$71,40 \leq$ Love of Money $<93,80$ & Ren dah & \\
$93,80 \leq$ Love of Money $<116,20$ & Cukup & 113,23 \\
$116,20 \leq$ Love of Money $<138,60$ & Tinggi & \\
$138,60 \leq$ Love of Money $<161,00$ & Sangat Tinggi & \\
\hline
\end{tabular}
Sumber: Data diolah, 2019

Hasil rata-rata jawaban responden sebesar 113,23 yang sebaran datanya cenderung ke kanan menunjukkan klasifikasi jawaban responden memiliki love of money yang cukup. Artinya, uang dinilai sangat penting bagi responden sebagai sarana untuk memenuhi kebutuhan, akan tetapi hasrat responden terhadap uang tidak terlalu besar.

Hasil penelitian ini sejalan dengan penelitian Charismawati (2011) yang menyimpulkan bahwa terdapat hubungan antara tingkat love of money pada mahasiswa akuntansi dengan persepsi etis. Semakin besar tingkat love of money mahasiswa akuntansi, maka akan semakin rendah tingkat persepsi etis. Penelitian 
lain yang memperkuat penelitian ini adalah penelitian Aziz dan Taman (2015) yang menyatakan bahwa love of money berpengaruh negatif terhadap persepsi etis mahasiswa akuntansi Universitas Negeri Yogyakarta dan didukung oleh penelitian yang dilakukan oleh Sugiantari dan Widanaputra (2016) yang menunjukkan bahwa love of money berpengaruh negatif pada persepsi mahasiswa akuntansi tentang krisis etika akuntan.

Individu dengan love of money yang tinggi memiliki rasa cinta yang begitu besar terhadap uang dan sangat mendewakan uang. Ketika individu ini ingin memenuhi hasrat terhadap uang, di saat itu pula timbul dilema-dilema etika dalam diri individu, dimana individu yang persepsi etisnya rendah, tidak mampu memproses persepsi etis yang lebih tinggi, sehingga tidak dapat melakukan kontrol terhadap keinginan individu akan uang. Hal ini sesuai dengan teori perkembangan moral kognitif yang menekankan kepada proses berpikir moral, apa yang dipikirkan seorang individu dalam menghadapi sebuah dilema etika (Mintchik \& Farmer, 2009 dalam Yeltshinta, 2013). Menurut Richmond (2001) dalam Sugiantari dan Widanaputra (2016) teori perkembangan moral kognitif mengasumsikan individu dengan pertimbangan etis rendah tidak mampu memproses pertimbangan etis yang lebih tinggi. Keinginan yang besar pada diri individu terhadap uang menjadikan individu tersebut kemudian buta dan lalai sehingga melakukan segala cara, termasuk jalan pintas sekalipun yang melanggar persepsi etisnya.

Berdasarkan hasil pengujian analisis regresi linier berganda pada Tabel 4 dapat diketahui bahwa nilai koefisien $\left(\beta_{2}\right)$ sebesar 0,289 dengan tingkat 
Ni Luh Putu Widia Ananda Sari dan A.A.G.P Widanaputra. Pengaruh ...

signifikansi sebesar 0,005. Sig. t pengaruh equity sensitivity pada persepsi etis mahasiswa akuntansi adalah 0,005 yang lebih kecil dari 0,05 yang berarti bahwa $\mathrm{H}_{0}$ ditolak dan $\mathrm{H}_{1}$ diterima. Hal ini menunjukkan bahwa equity sensitivity berpengaruh terhadap persepsi etis mahasiswa akuntansi. Hipotesis pertama yang menyatakan semakin tinggi equity sensitivity maka semakin tinggi persepsi etis terbukti.

Hasil penelitian ini sejalan dengan penelitian yang dilakukan oleh Utami (2005) menyebutkan bahwa mahasiswa jurusan akuntansi yang termasuk dalam kategori benevolent secara signifikan terbukti memiliki perilaku yang lebih etis daripada mahasiswa jurusan akuntansi yang termasuk dalam kategori entitleds. Hasil penelitian yang dilakukan oleh Widiastuti dan Nugroho (2015) menemukan bukti bahwa terdapat pengaruh equity sensitivity terhadap perilaku etis auditor. Kusuma dan Budisantosa (2016) juga mengemukakan bahwa equity sensitivity berpengaruh positif terhadap perilaku etis auditor.

Equity sensitivity dapat dipahami sebagai keadilan yang dirasakan oleh individu dengan membandingkannya dengan individu lain. Individu dapat dikategorikan menjadi 3 yaitu benevolent, equity sensitivity, dan entitleds. Individu dengan benevolent adalah individu yang lebih suka memberi, dalam artian individu ini tidak mempersalahkan jika input lebih besar daripada outcome jika dibandingkan dengan comparison person. Individu dengan entitleds adalah individu yang lebih suka menerima, dalam artian individu ini akan merasa kurang puas jika outcome yang didapatkannya lebih kecil dari input jika dibandingkan dengan comparison person. Equity sensitivity adalah individu yang merasa puas 
jika input dan outcome individu tersebut sama dengan input dan outcome comparison person. Hal ini sejalan dengan teori keseimbangan yang menyatakan bahwa jika tingkat rasio perbandingan individu menunjukkan keseimbangan dengan rasio individu lainnya, maka individu tersebut akan merasa puas. Berdasarkan hasil analisis dalam penelitian ini, jumlah meanscore adalah 20,7. Jumlah mahasiswa dengan benevolent adalah sebanyak 29 mahasiswa dan entitleds sebanyak 36 mahasiswa.

Berdasarkan hasil pengujian analisis regresi linier berganda pada Tabel 6 dapat diketahui bahwa nilai koefisien $\left(\beta_{3}\right)$ sebesar $-0,210$ dengan tingkat signifikansi sebesar 0,000. Sig. t pengaruh Machiavellian pada persepsi etis mahasiswa akuntansi adalah 0,000 yang lebih kecil dari 0,05 yang berarti bahwa $\mathrm{H}_{0}$ ditolak dan $\mathrm{H}_{1}$ diterima. Hal ini menunjukkan bahwa Machiavellian berpengaruh terhadap persepsi etis mahasiswa akuntansi. Hipotesis pertama yang menyatakan semakin tinggi Machiavellian maka semakin rendah persepsi etis terbukti.

Hasil penelitian ini sejalan dengan penelitian yang dilakukan oleh Aziz dan Taman (2015) menyatakan bahwa Machiavellian berpengaruh negatif terhadap persepsi etis mahasiswa akuntansi Universitas Negeri Yogyakarta. Penelitian yang dilakukan oleh Novitasari (2016) juga menyatakan bahwa perilaku Machiavellian berpengaruh negatif terhadap persepsi etis mahasiswa akuntansi Universitas Negeri Yogyakarta. Prabowo (2016) menyatakan bahwa secara parsial Machiavellianisme berpengaruh negatif terhadap persepsi etis mahasiswa akuntansi tingkat akhir di Universitas Dian Nuswantoro Semarang. 
Ni Luh Putu Widia Ananda Sari dan A.A.G.P Widanaputra. Pengaruh ...

Selain dipengaruhi oleh love of money dan equity sensitivity, persepsi etis mahasiswa akuntansi juga dipengaruhi oleh perilaku Machiavellian. Perilaku Machiavellian dianggap sebagai faktor tambahan yang mempengaruhi seseorang untuk berprilaku tidak etis. Mc Laughlin (1970) dalam Novitasari (2016) menyebutkan bahwa seseorang dengan perilaku Machiavellian cenderung untuk berbohong. Machiavellian didefinisikan sebagai suatu proses dimana manipulator mendapatkan imbalan lebih ketika melakukan memanipulasi, sementara orang lain mendapatkan kurang tanpa melakukan manipulasi, setidaknya dalam konteks langsung (Richmond, 2001 dalam Yeltshinta, 2013). Individu dengan Machiavellian adalah seorang manipulator dengan moral rendah yang melakukan memanipulasi demi untuk mendapatkan imbalan/ reward. Hal ini sejalan dengam teori perkembangan moral kognitif yang menyatakan bahwa ada kategorisasi dan klasifikasi perkembangan moral ke dalam tiga tahap yang berbeda. Tahapan yang paling rendah (pre-conventional), individu akan melakukan suatu tindakan karena berdasarkan imbalan.

Penelitian ini diharapkan dapat memberikan tambahan bukti empiris yang hasilnya dapat memperkuat mengenai teori perkembangan moral kognitif dan teori keseimbangan dalam menjelaskan hubungan pengaruh love of money, equity sensitivity dan Machiavellian pada persepsi etis mahasiswa akuntansi. Ketika individu ini ingin memenuhi hasrat terhadap uang, di saat itu pula timbul dilemadilema etika dalam diri individu, dimana individu yang persepsi etisnya rendah, tidak mampu memproses persepsi etis yang lebih tinggi, sehingga tidak dapat melakukan kontrol terhadap keinginan individu akan uang. Hal ini sesuai dengan 
teori perkembangan moral kognitif yang menekankan kepada proses berpikir moral, apa yang dipikirkan seorang individu dalam menghadapi sebuah dilema etika (Mintchik \& Farmer, 2009 dalam Yeltshinta, 2013). Menurut Richmond (2001) dalam Sugiantari dan Widanaputra (2016) teori perkembangan moral kognitif mengasumsikan individu dengan pertimbangan etis rendah tidak mampu memproses pertimbangan etis yang lebih tinggi.

Equity sensitivity adalah individu yang merasa puas jika input dan outcome individu tersebut sama dengan input dan outcome comparison person. Hal ini sejalan dengan teori keseimbangan yang menyatakan bahwa jika tingkat rasio perbandingan individu menunjukkan keseimbangan dengan rasio individu lainnya, maka individu tersebut akan merasa puas.

Individu dengan Machiavellian adalah seorang manipulator dengan moral rendah yang melakukan memanipulasi demi untuk mendapatkan imbalan/ reward. Hal ini sejalan dengam teori perkembangan moral kognitif yang menyatakan bahwa ada kategorisasi dan klasifikasi perkembangan moral ke dalam tiga tahap yang berbeda. Tahapan yang paling rendah (pre-conventional), individu akan melakukan suatu tindakan karena berdasarkan imbalan.

Hasil penelitian ini diharapkan dapat menjadi sarana untuk menambah wawasan bagi pembaca, khususnya mahasiswa akuntansi yang sedang menempuh pendidikan di bangku perkuliahan untuk mempersiapkan perilaku etis sebelum memasuki dunia kerja, serta memberikan kontribusi sebagai bahan evaluasi bagi universitas mengenai pentingnya penanaman konsep perilaku etis. 
Ni Luh Putu Widia Ananda Sari dan A.A.G.P Widanaputra. Pengaruh ...

Mahasiswa adalah calon dari akuntan, maka dari itu mahasiswa diharapkan untuk senantiasa berprilaku etis dan menghindari perilaku yang berkaitan dengan pelanggaran etika, norma, serta peraturan yang berlaku. Bagi peneliti yang ingin melakukan penelitian sejenis, dapat mengembangkan penelitian ini dengan menambahan faktor-faktor lain seperti kecerdasan spiritual, ethical sensitivity, serta faktor-faktor lainnya yang memiliki pengaruh pada persepsi etis yang tidak diteliti dalam penelitian ini. Bagi penelitian selanjutnya juga dapat mengembangkan lokasi penelitian ke universitas lain, baik negeri maupun swasta, ataupun mengembangkan objek penelitian kepada auditor.

\section{SIMPULAN}

Love of money berpengaruh negatif pada persepsi etis mahasiwa akuntansi. Hal ini berarti semakin tinggi love of money, maka semakin rendah persepsi etis mahasiswa akuntansi.

Equity sensitivity berpengaruh positif pada persepsi etis mahasiswa akuntansi. Hal ini berarti semakin tinggi equity sensitivity, maka semakin tinggi persepsi etis mahasiswa akuntansi.

Machiavellian berpengaruh negatif pada persepsi etis mahasiswa akuntansi. Hal ini berarti semakin tinggi Machiavellian, maka semakin rendah persepsi etis mahasiswa akuntansi.

Mahasiswa adalah calon dari akuntan, maka dari itu mahasiswa diharapkan untuk senantiasa berprilaku etis dan menghindari perilaku yang berkaitan dengan pelanggaran etika, norma, serta peraturan yang berlaku. 
Bagi peneliti yang ingin melakukan penelitian sejenis, dapat mengembangkan penelitian ini dengan menambahan faktor-faktor lain seperti kecerdasan spiritual, ethical sensitivity, serta faktor-faktor lainnya yang memiliki pengaruh pada persepsi etis yang tidak diteliti dalam penelitian ini.

Bagi penelitian selanjutnya dapat mengembangkan lokasi penelitian ke universitas lain, baik negeri maupun swasta, ataupun mengembangkan objek penelitian kepada auditor.

\section{REFERENSI}

Allen, R. S., Allen, D. E., Karl, K., \& White, C. S. (2015). Are Millennials Really an Entitled Generation? An Investigation into Generational Equity Sensitivity Differences. Journal of Business Diversity, 15(2), 14-26.

Aziz, Toriq Ibnu dan Taman, A. (2015). Pengaruh Love of Money dan Machiavellian terhadap Persepsi Etis Mahasiswa Akuntansi (Studi Empiris pada Mahasiswa Akuntansi UNY Angkatan 2013 dan Angkatan 2014). Jurnal Nominal, 4(2), 31-44. https://doi.org/10.21831/nominal.v4i2.7998

Belschak, F. D., Den Hartog, D. N., \& Kalshoven, K. (2015). Leading Machiavellians: How to Translate Machiavellians' Selfishness Into ProOrganizational Behavior. Journal of Management, 41(7), 1934-1956. https://doi.org/. https://doi.org/10.1177/0149206313484513

Charismawati, C. D. (2011). Analisis Hubungan Antara Love of Money dengan Persepsi Etika Mahasiswa Akuntansi. Diponegoro Journal of Accounting.

Chen, J., Tang, T. L.-P., \& Tang, N. (2014). Temptation, Monetary Intelligence (Love of Money), and Environmental Context on Unethical Intentions and Cheating. Journal of Business Ethics, 123(2), 197-219. https://doi.org/https://doi.org/10.1007/s10551-013-1783-2

Christie, R. and G. L. F. L. G. (1970). Studies in Machiavellianism. https://doi.org/https://doi.org/10.1016/C2013-0-10497-7

Fatoki, O. (2015). Gender, Academic Major and the Love of Money by University Students in South Africa. Gender and Behaviour, 13(1), 6632-6639.

Hadi Susanto dan Rekan. (2018). Profil Usaha Drs. Hadi Susanto dan Rekan. 
Diunduh dari website: https://www.profilusaha.com/drs-hadi-susanto-rekan

K Miller, B., L Smart, D., \& L Rechner, P. (2015). Confirmatory Factor Analysis of The Machiavellian Personality Scale. Personality and Individual Differences, 82 , 120-124. https://doi.org/https://doi.org/10.1016/j.paid.2015.03.022

Kase, Marce Sherly, D. (2017). Conscientiousness dan Agreeableness sebagai Pemoderasi Pengaruh Love Of Money pada Tax Evasion Tendency Mahasiswa Magister Akuntansi. E-Jurnal Ekonomi Dan Bisnis Universitas Udayana, $6(10)$ 3665-3696. https://doi.org/https://ojs.unud.ac.id/index.php/EEB/article/view/27337

Kohlberg L. (2008). The Development of Children's Orientations Toward a Moral Order. Journal Abbreviation: Human Development, 5(1). https://doi.org/10.1159/000112530

Kusuma, RND dan Budisantosa, A. T. (2016). Analisis Pengaruh Equity Sensitivity dan Ethical Sensitivity Terhadap Perilaku Etis Auditor. Modus Journals, $29(1)$

105-117. https://doi.org/https://doi.org/10.24002/modus.v29i1.1029

Lemrová, S., Reiterová, E., Fatěnová, R. et al. (2014). Money is Power: Monetary Intelligence-Love of Money and Temptation of Materialism Among Czech University Students. Journal of Business Ethics, 125(2), 329-348. https://doi.org/https://doi.org/10.1007/s10551-013-1915-8

Luna-Arocas, R., \& Tang, T. L.-P. (2015). Are You Satisfied With Your Pay When You Compare? It Depends on Your Love of Money, Pay Comparison Standards, and Culture. Journal of Business Ethics, 128(2), 279-289. https://doi.org/https://doi.org/10.1007/s10551-014-2100-4

Miles, Edward W, Richard, John D. Hatfield . Huseman, C. (1994). Equity Sensitivity and Outcome Importance. Journal of Organization Behavior, 15(7), 585-596. https://doi.org/https://doi.org/10.1002/job.4030150704

Mueller, Stephen L. and Clarke, L. D. (1998). Political-Economic Context and Sensitivity to Equity: Differences between the United States and the Transition Economies of Central and Eastern Europe. Academy of Management Journal, 41(3). https://doi.org/https://doi.org/10.5465/256910

Novitasari, E. D. dan S. (2016). Pengaruh Love of Money dan Perilaku Machiavellian terhadap Persepsi Etis Mahasiswa Akuntansi (Studi Kasus pada Mahasiswa S1 Program Studi Akuntansi Angkatan 2010 dan 2011 Fakultas Ekonomi Universitas Negeri Yogyakarta). Jurnal Profita: Kajian Ilmu Akuntansi, 4(3), 1-22. 
Pekdemir, I. M., \& Turan, A. (2015). The Relationships Among Love of Money, Machiavellianism and Unethical Behavior. Canadian Social Science, 11(6), 48-59. https://doi.org/DOI:10.3968/7112

Prabowo, D. S. (2016). Analisis Pengaruh Paham Machiavellianisme dan Aspek Love of Money Terhadap Persepsi Etis Mahasiswa Akuntansi Tingkat Akhir di Kota Semarang. E-Prints UDiNus.

Rindayanti, D. S. B. (2017). Hubungan antara Love of money, Machiavellian dengan Persepsi Etis: Analisis Berdasarkan Perspektif Gender. Jurnal Ilmu Akuntansi Universitas PGRI Yogyakarta, 10(2), 261 - 272.

Sugiantari, Ni Kadek dan Widanaputra, A. A. G. . (2016). Pengaruh Idealisme, Relativisme, dan Love of money pada Persepsi Mahasiswa Akuntansi Tentang Krisis Etika Akuntan. E-Jurnal Akuntansi Universitas Udayana, 17(3), 2474-2502.

Susanti, B. (2014). Pengaruh Locus Of Control, Equity sensitivity, Ethical Sensitivity dan Gender Terhadap Perilaku Etis Akuntan (Studi Empiris Kantor Akuntan Publik Wilayah Padang dan Pekanbaru). E-Journal Universitas Negeri Padang, 2(2) 1-15.

Tang, Thomas Li-Ping, Tang, David Shin-Hsiung, Arocas, R. L. (2004). Money Profiles: The Love of Money, Attitudes, and Needs. Personnel Review, 34(5), 603 - 618. https://doi.org/10.1108/00483480510612549

Tang, Thomas Li-Ping and Chen, Y.-J. (2008). Intelligence Vs. Wisdom: The Love of money, Machiavellianism, and Unethical Behavior across College Major and Gender. Journal of Business Ethics, 82(1), 1-26. https://doi.org/https://doi.org/10.1007/s10551-007-9559-1

Tang, Thomas Li-Ping dan Chiu, R. K. (2003). Income, Money Ethic, Pay Satisfaction, Commitment, and Unethical Behavior: Is the Love of money the Root of Evil for Hong Kong Employees? Journal of Business Ethics, 46(1), 13-30. https://doi.org/https://doi.org/10.1023/A:102473161

Tang, T. L. (1992). The Meaning of Money Revisited. Journal of Organization Behavior, 13(2), 197-202. https://doi.org/https://doi.org/10.1002/job.4030130209

Telkom Indonesia. (2018). Profil dan Riwayat Singkat Telkom. Diunduh dari website:https://www.telkom.co.id/servlet/tk/about/id_ID/stocklanding/profildan-riwayat-singkat.html

Utami, R. D. (2005). Analisis Perbedaan Faktor-faktor Individual Terhadap Persepsi Perilaku Etis Mahasiswa: Studi Kasus pada Mahasiswa Jurusan 
Ni Luh Putu Widia Ananda Sari dan A.A.G.P Widanaputra. Pengaruh ...

Akuntansi dan Manajemen di Perguruan Tinggi Se-Karesidenan Surakarta. Tesis. Universitas Diponegoro.

Widiastuti, Eni dan Nugroho, M. A. (2015). Pengaruh Orientasi Etis, Equity sensitivity, dan Budaya Jawa terhadap Perilaku Etis Auditor pada Kantor Akuntan Publik di Yogyakarta. Jurnal Nominal, 4(1), 32-48. https://doi.org/https://doi.org/10.21831/nominal.v4i1.6886

Yeltshinta, R. (2013). Love of Money, Pertimbangan Etis, Machiavellian, Questionable Action: Implikasi Pengambilan Keputusan Etis Terhadap Mahasiswa Akuntansi dengan Variabel Moderasi Gender. Diponegoro Journal of Accounting, 2(3), 1-11. ISSN : 2337-3806. 